\title{
Reproductive Phenology of Pterocladiella capillacea (Rhodophyta: Gelidiales) from Southern Baja California, Mexico ${ }^{1}$
}

\author{
Elisa Servière-Zaragoza $a^{2}$ and Ricardo Scrosati ${ }^{2,3}$
}

\begin{abstract}
The abundance of vegetative and reproductive fronds of Pterocladiella capillacea (Gelidiaceae) from an intertidal population at Lobos Point, on the $\mathrm{Pa}$ cific coast of southern Baja California, Mexico, was measured bimonthly between March 1998 and January 1999. Fronds with tetrasporic sori occurred throughout the year, although in low percentages with respect to the total amount of fronds: monthly means ranged between $0.5 \%$ (May) and $6.0 \%$ (July). Fronds with cystocarps and fronds with spermatangia were found only in January, with even lower percentages: $0.15 \%$ and $0.10 \%$, respectively. The overall predominance of reproductive tetrasporophytic fronds over reproductive gametophytic fronds is common in natural populations of the Gelidiaceae. Reproductive phenology, however, varies widely within this family, even within the same species, as is the case for $P$. capillacea. Little is known about factors affecting the reproductive phenology of this cosmopolitan alga; field and laboratory studies are needed to provide a reliable predictive framework.
\end{abstract}

Most Red SEAweeds (Rhodophyta) have a triphasic life history, involving an alternation of gametophytes, carposporophytes, and tetrasporophytes (Graham and Wilcox 2000). Only gametophytes and tetrasporophytes constitute free-living individuals; carposporophytes occur within female gametophytes. This kind of life history does not occur in animals or vascular plants, so an increasing number of ecological and evolutionary studies are being done on it (e.g., Hughes and Otto 1999, Scrosati and DeWreede 1999). A primary step in life-history studies is assessing the abundance of reproductive phases in natural populations. Species of the family Gelidiaceae (Gelidiales) are common on several

${ }^{1}$ This work was funded by CIBNOR research grants ABM-8 (to E.S.-Z.) and RM-7 (to R.S.). Manuscript accepted 23 November 2001.

${ }^{2}$ Northwest Biological Research Center (CIBNOR), Ap. 128, La Paz, 23000 Baja California Sur, Mexico.

${ }^{3}$ Corresponding author: Current address: University of British Columbia, Department of Botany, Vancouver, British Columbia V6T 174, Canada (E-mail: scrosati @axion.net).

Pacific Science (2002), vol. 56, no. 3:285-290

(C) 2002 by University of Hawai'i Press

All rights reserved coasts around the world, so their reproductive characteristics have been studied by several researchers. For this family, gametophytes and tetrasporophytes are isomorphic and tetrasporophytic fronds generally predominate over gametophytic fronds in natural populations (Akatsuka 1986, Santelices 1988).

Pterocladiella capillacea (S. G. Gmelin) Santelices \& Hommersand is a common species of the Gelidiaceae in several warm-temperate and tropical coasts from the Atlantic and Pacific Oceans and adjacent seas (Stewart 1968, Lawson and John 1987, Ramírez and Santelices 1991, Felicini and Perrone 1994, González-González et al. 1996, Silva et al. 1996, Santelices and Hommersand 1997, Coll and Oliveira 1999, Littler and Littler 2000, Neto 2000). Thus, studies on the geographic variation of its reproductive phenology may help to understand ecological and evolutionary factors affecting seaweed life-history traits. Phenological studies on $P$. capillacea have been done for a number of sites worldwide (see Discussion). In this paper we describe the reproductive phenology of $P$. capillacea from southern Baja California, Mexico. This species has already been reported from the Mexican Pacific coast (González-González et al. 1996), but no studies on its reproductive phenology have been done for this area. Be- 
cause populations of the Gelidiaceae are generally dominated by those with tetrasporophytic fronds, this pattern was also expected for $P$. capillacea from southern Baja California. However, its reproductive phenology was impossible to predict because this may depend on species, latitude, local conditions, or year for the Gelidiaceae (Akatsuka 1986, Santelices 1988).

\section{MATERIALS AND METHODS}

The thallus of Pterocladiella capillacea consists of branched prostrate stolons and several upright fronds (see a picture of fronds from the study site in Scrosati 2002). We studied an intertidal population of $P$. capillacea from Lobos Point $\left(23^{\circ} 25^{\prime} \mathrm{N}, 110^{\circ} 14^{\prime} \mathrm{W}\right)$, on the west (Pacific) coast of the Baja California Peninsula, Mexico, between March 1998 and January 1999. At this site, the highest tidal amplitude is about $2 \mathrm{~m}$. Pterocladiella capillacea is the dominant species between about 0.3 and $1.5 \mathrm{~m}$ above mean lower low water on vertical rocky walls directly exposed to waves, although its upper limit may be higher in some places due to topography and wave action. We could not make subtidal observations because waves were usually large at this site, but the lowest tides allowed us to see the rocky substrate a few tens of centimeters below the 0.3-m mark, where no $P$. capillacea was visible. Seawater temperature at Lobos Point varied between $18^{\circ} \mathrm{C}$ (winter) and $29^{\circ} \mathrm{C}$ (summer) between March 1998 and March 1999 (R.S., unpubl. data). This period included consecutive El Niño and La Niña events in the tropical Pacific (Enfield 2001). Identification to species level was done according to Stewart (1976). A recent taxonomic comparison based on $r b c \mathrm{~L}$ gene sequences between samples of $P$. capillacea from Lobos Point and samples from other sites around the world confirmed the taxonomic identity of the Lobos Point entity (D. W. Freshwater, pers. comm.).

Our sampling dates were 26 March, 24 May, 21 July, 19 September, and 19 November 1998, and 18 January 1999. On each date, $P$. capillacea was scraped completely from 10 quadrats $\left(25 \mathrm{~cm}^{2}\right)$ that were randomly located along both sides of a transect $4 \mathrm{~m}$ long placed horizontally in the middle of a representative stand of this species. The position of quadrats was recorded to avoid later resampling. For each quadrat, the amount of vegetative and reproductive fronds was determined. To assess reproductive condition, all fronds were inspected for the presence of tetrasporic sori or cystocarps (without quantifying their abundance or assessing their maturity) under a dissecting microscope. Cystocarps were found only in January, so spermatangia were looked for only in the November and January samples. To detect spermatangia, fronds were previously stained with aniline blue, following Hommersand and Fredericq (1996). There is currently no quick method for the determination of the life-history phase of vegetative fronds for the Gelidiaceae. For other groups, such as the Gigartinaceae, the resorcinol test is applied to frond samples to identify their life-history phase, based on a colorimetric reaction (Garbary and DeWreede 1988). Such a test relies on the presence of carrageenan in cell walls, but the Gelidiaceae have agar, instead of carrageenan (see Güven and Güler 1979, for P. capillacea). Thus, our estimation of the relative abundance of lifehistory phases for P. capillacea was based on counts of reproductive fronds, with limitations that are outlined in Results.

\section{RESULTS AND DISCUSSION}

Pterocladiella capillacea was always present at Lobos Point between March 1998 and March 1999 (only a visual inspection was done in March 1999). The temporal variation of total (vegetative and reproductive) frond density was described and statistically analyzed in Scrosati and Servière-Zaragoza (2000); basically, total frond density was higher in spring and summer and lower in fall and winter, ranging between $7 \pm 1$ fronds $\mathrm{cm}^{-2}$ (mean $\left.\pm \mathrm{SE} ; n=10\right)$ in November and $16 \pm 1$ fronds $\mathrm{cm}^{-2}$ in May (area measurements refer to substrate area). Fronds with tetrasporic sori occurred throughout the year (Figure 1), although they always represented a low percentage with respect to the total amount of fronds: monthly means $(n=10)$ 


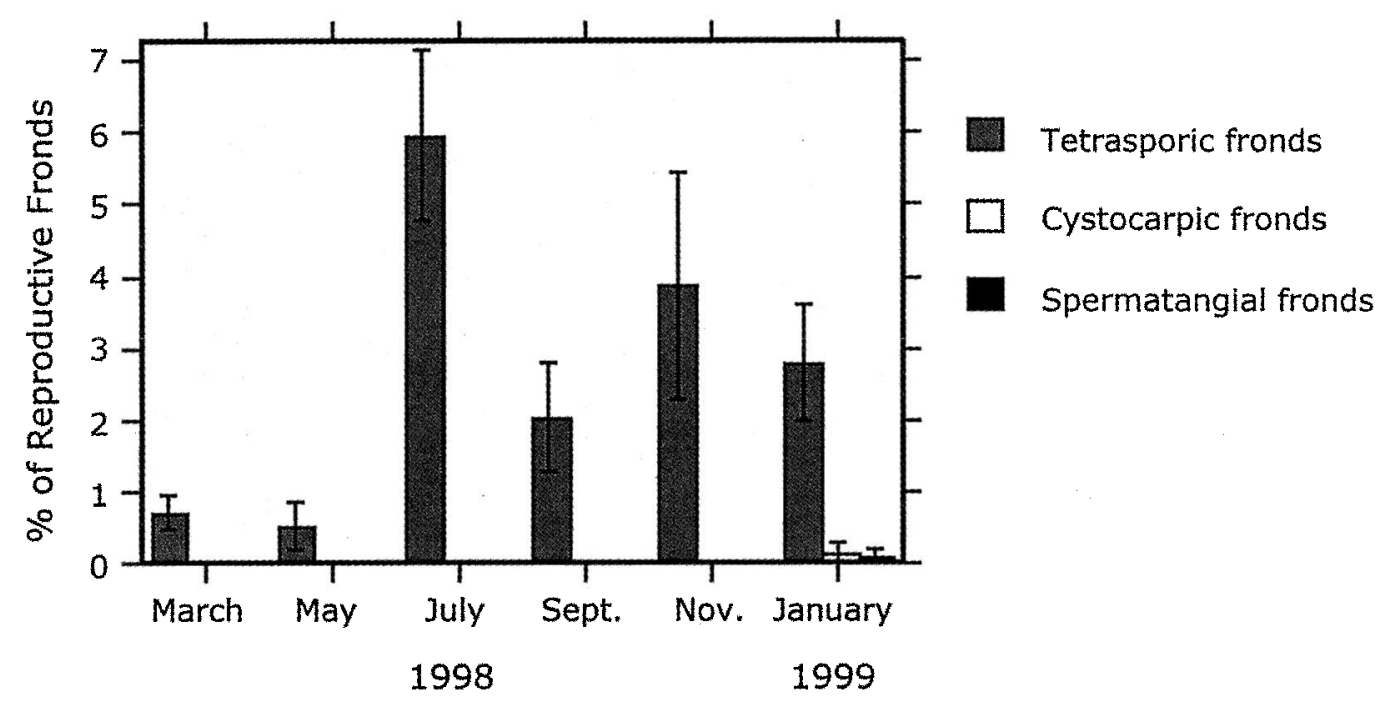

Time

Figure 1. Pterocladiella capillacea from Lobos Point: temporal variation of the percentage of reproductive fronds (mean $\pm \mathrm{SE} ; n=10$ ) with respect to the total amount of fronds (see text for details on sampling design).

ranged between $0.5 \%$ in May and $6.0 \%$ in July. Fronds with cystocarps and fronds with spermatangia were only found in January (Figure 1) and were even less abundant than tetrasporic fronds. On average $(n=10)$, cystocarpic fronds represented $0.15 \%$ of the total amount of fronds, whereas spermatangial fronds represented $0.10 \%$.

The higher abundance of reproductive tetrasporophytic fronds over reproductive gametophytic fronds suggests that tetrasporophytes are more abundant than gametophytes in this population. However, this should be regarded with caution, because genets (each thallus that develops from a single spore [Scrosati 2001a]) were impossible to identify in the field due to high frond densities, stolon interminglement, and possibly the breakup of genets into clonal fragments (sensu Eriksson and Jerling 1990). In addition, gametophytes and tetrasporophytes may not become reproductive to the same degree, so counts of reproductive fronds may not accurately represent the abundance of a given life-history phase. Nonetheless, according to the available data, the most consistent interpretation is that tetrasporophytes dominate this population of $P$. capillacea. This agrees with the pattern found for another species of Gelidiaceae from the Pacific coast of California and Baja California, Gelidium robustum (Gardner) Hollenberg \& Abbott (Barilotti and Silverthorne 1972, Guzmán del Próo and de la Campa de Guzmán 1979, RodríguezGarza and Espinoza-Ávalos 1987, EspinozaÁvalos 1996), and with the pattern generally described for the Gelidiaceae (Akatsuka 1986, Santelices 1988). However, those studies were also based on the density of reproductive fronds, so developing techniques for genet identification in natural populations is needed to obtain more solid conclusions (Scrosati 2001a).

In contrast to the expected tetrasporophyte predominance for $P$. capillacea from Lobos Point, no particular pattern was expected for its reproductive phenology. The reproductive phenology of $P$. capillacea may differ widely among sites worldwide, but the main factors that affect it are poorly understood (Felicini and Perrone 1994). For example, variation in reproductive phenology may occur at local scale, as found for intertidal and subtidal populations from the San Diego (California) area (Stewart 1968). Variation may also occur at regional scale, as the comparison between 
those San Diego populations and our Lobos Point population indicates. Stewart (1968) generally found tetrasporic fronds throughout the year, as we did in Lobos Point, but she also found cystocarpic and spermatangial fronds throughout the year, unlike our findings. Variation in reproductive phenology may also occur at global scale. For example, Santelices (1977) found tetrasporic fronds between August and June on the islands of Kaua'i, O'ahu, Maui, and Hawai'i and cystocarpic fronds in April and June on O'ahu and in April, August, and November on Maui. For central and southern Brazil, collections done between the 1950s and 1980s suggest that reproductive tetrasporophytic and gametophytic fronds occur throughout the year in that region as a whole, although regional differences could not be assessed (Ugadim 1988). In the Azores Islands, Neto (2000) recorded tetrasporic fronds mostly between summer and winter, but he found only one cystocarpic frond (in April) during his study. In Atlantic France and Spain, reproductive tetrasporophytic and gametophytic fronds were observed between June and October (Dixon and Irvine 1977). In the British Isles, which represent the northern limit of distribution of $P$. capillacea in Europe, reproductive fronds were never found (Dixon and Irvine 1977). Environmental extremes related to latitude and elevation on the shore are thought to inhibit sexual reproduction and spore production (Felicini and Perrone 1994); the latitude effect possibly results from temperature limits for reproduction being narrower than for growth and survival in red seaweeds (Kain and Norton 1990).

Future insights on the relationship between reproductive phenology and abiotic factors might be obtained by doing multifactorial laboratory experiments or by monitoring a number of populations and abiotic factors simultaneously at a variety of spatial scales. Monitoring should be done for more than 1 year, because interannual abiotic differences may sometimes be large, greatly affecting seaweed dynamics (see Ladah et al. 1999, Hernández-Guerrero et al. 2000, and Scrosati $2001 b$ for seaweeds from Baja California). Ultimately, inferences about the evo- lution of life-history traits could be done at the species level, following the approach of Franco and Silvertown (1997) for terrestrial plants.

\section{ACKNOWLEDGMENTS}

We thank Joan G. Stewart, Leonard J. Dyck, and an anonymous reviewer for their helpful comments. The initial stay of R.S. in Mexico was possible thanks to the Cátedra Patrimonial de Excelencia program of the National Science and Technology Council of Mexico (CONACYT). Financial support to both authors from the Sistema Nacional de Investigadores (SNT) program of CONACYT is also acknowledged.

\section{Literature Cited}

Akatsuka, I. 1986. Japanese Gelidiales (Rhodophyta), especially Gelidium. Oceanogr. Mar. Biol. Annu. Rev. 24:171-263.

Barilotti, D. C., and W. Silverthorne. 1972. A resource management study of Gelidium robustum. Proc. Int. Seaweed Symp. 7:255261.

Coll, J., and E. C. Oliveira. 1999. The benthic marine algae of Uruguay. Bot. Mar. 42:129-135.

Dixon, P. S., and L. M. Irvine. 1977. Seaweeds of the British Isles. Vol. 1. Rhodophyta. Part 1. Introduction, Nemaliales, Gigartinales. British Museum (Natural History), London.

Enfield, D. B. 2001. Evolution and historical perspective of the 1997-1998 El NiñoSouthern Oscillation event. Bull. Mar. Sci. 69:7-25.

Eriksson, O., and L. Jerling. 1990. Hierarchical selection and risk spreading in clonal plants. Pages 79-94 in J. van Groenendael and $\mathrm{H}$. de Kroon, eds. Clonal growth in plants: Regulation and function. SPB Academic Publishers, The Hague.

Espinoza-Ávalos, J. 1996. Size structure and reproduction of Gelidium robustum (Rhodophyta) in the central part of the Baja California Peninsula, Mexico. Cienc. Mar. 22:415-426.

Felicini, G. P., and C. Perrone. 1994. Pter- 
ocladia. Pages 283-344 in I. Akatsuka, ed. Biology of economic algae. SPB Academic Publishers, The Hague.

Franco, M., and J. Silvertown. 1997. Life history variation in plants: An exploration of the fast-slow continuum hypothesis. Pages 210-227 in J. Silvertown, M. Franco, and J. L. Harper, eds. Plant life histories: Ecology, phylogeny, and evolution. Cambridge University Press, Cambridge.

Garbary, D. J., and R. E. DeWreede. 1988. Life history phases in natural populations of Gigartinaceae (Rhodophyta): Quantification using resorcinol. Pages 174-178 in C. S. Lobban, D. J. Chapman, and B. P. Kremer, eds. Experimental phycology: A laboratory manual. Cambridge University Press, Cambridge.

González-González, J., M. Gold-Morgan, H. León-Tejera, C. Candelaria, D. LeónÁlvarez, E. Servière-Zaragoza, and D. Fragoso. 1996. Catálogo onomástico (nomenclátor) y bibliografía indexada de las algas bentónicas marinas de México. Cuad. Inst. Biol. 29:1-492.

Graham, L. E., and L. W. Wilcox. 2000. Algae. Prentice Hall, Upper Saddle River.

Güven, K. C., and E. Güler. 1979. Studies on Pterocladia capillacea (Gmel.) Born. et Thur. Part I. Phytochemical investigations. Pages 681-692 in H. A. Hoppe, T. Levring, and Y. Tanaka, eds. Marine algae in pharmaceutical science. Walter de Gruyter, Berlin.

Guzmán del Próo, S. A., and S. de la Campa de Guzmán. 1979. Gelidium robustum (Florideophyceae), an agarophyte of Baja California, Mexico. Proc. Int. Seaweed Symp. 9:303-308.

Hernández-Guerrero, C. J., M. CasasValdez, S. Ortega-García, and S. Hernández-Vázquez. 2000. Effect of climatic variation on the relative abundance of the red alga Gelidium robustum in Baja California Sur, Mexico. J. Appl. Phycol. 12:177-183.

Hommersand, M. H., and S. Fredericq. 1996. Vegetative and reproductive development of Pterocladia capillacea (Gelidiales, Rhodophyta) from La Jolla, California. Nova Hedwigia 112:147-160.

Hughes, J. S., and S. P. Otto. 1999. Ecology and the evolution of biphasic life cycles. Am. Nat. 154:306-320.

Kain, J. M., and T. A. Norton. 1990. Marine ecology. Pages 377-422 in K. M. Cole and R. G. Sheath, eds. Biology of the red algae. Cambridge University Press, Cambridge.

Ladah, L. B., J. A. Zertuche-González, and G. Hernández-Carmona. 1999. Giant kelp (Macrocystis pyrifera, Phaeophyceae) recruitment near its southern limit in Baja California after mass disappearance during ENSO 1997-1998. J. Phycol. 35:11061112.

Lawson, G. W., and D. M. John. 1987. The marine algae and coastal environment of tropical West Africa, 2nd ed. Gebrüder Borntraeger, Berlin.

Littler, D. S., and M. M. Littler. 2000. Caribbean reef plants. OffShore Graphics, Washington, D.C.

Neto, A. I. 2000. Observations on the biology and ecology of selected macroalgae from the littoral of São Miguel (Azores). Bot. Mar. 43:483-498.

Ramírez, M. E., and B. Santelices. 1991. Catálogo de las algas marinas bentónicas de la costa templada del Pacífico de Sudamérica. Monogr. Biol. 5:1-437.

Rodríguez-Garza, H., and J. EspinozaÁvalos. 1987. Variación de fases reproductivas de Gelidium robustum (Gard.) Holl. \& Abbott en siete mantos algales de la península de Baja California, México. Invest. Mar. Cent. Interdiscip. Cienc. Mar. 3:7986.

Santelices, B. 1977. A taxonomic review of Hawaiian Gelidiales (Rhodophyta). Pac. Sci. 31:61-84.

. 1988. Synopsis of biological data on the seaweed genera Gelidium and Pterocladia (Rhodophyta). FAO Fish. Synop. 145:1-55.

Santelices, B., and M. Hommersand. 1997. Pterocladiella, a new genus in the Gelidiaceae (Gelidiales, Rhodophyta). Phycologia 36:114-119.

Scrosati, R. 2001a. Demographic studies on genets of clonal red seaweeds: Current limitations and proposed solutions using genetic markers from experimental populations. Hidrobiológica 11:149-155. 
- 2001b. Population dynamics of Caulerpa sertularioides (Chlorophyta: Bryopsidales) from Baja California, Mexico, during El Niño and La Niña years. J. Mar. Biol. Assoc. U.K. 81:721-726.

2002. Morphological plasticity and apparent loss of apical dominance following the natural loss of the main apex in Pterocladiella capillacea (Rhodophyta, Gelidiales) fronds. Phycologia 41: 96-98.

Scrosati, R., and R. E. DeWreede. 1999. Demographic models to simulate the stable ratio between ecologically similar gametophytes and tetrasporophytes in populations of the Gigartinaceae (Rhodophyta). Phycol. Res. 47:153-157.

Scrosati, R., and E. Servière-Zaragoza. 2000. Ramet dynamics for the clonal seaweed Pterocladiella capillacea (Rhodophyta, Gel- idiales): A comparison with Chondrus crispus and with Mazzaella cornucopiae (Gigartinales). J. Phycol. 36:1061-1068.

Silva, P. C., P. W. Basson, and R. L. Moe. 1996. Catalogue of the benthic marine algae of the Indian Ocean. University of California Press, Berkeley.

Stewart, J. G. 1968. Morphological variation in Pterocladia pyramidale. J. Phycol. 4:7684.

2. 1976. Family Gelidiaceae. Pages 340-352 in I. A. Abbott and G. J. Hollenberg, eds. Marine algae of California. Stanford University Press, Stanford.

Ugadim, Y. 1988. Estudo comparado de Gelidium coarctatum Kuetzing e Pterocladia capillacea (Gmelin) Bornet et Thuret (Rhodophyta-Gelidiaceae) no litoral brasileiro. Gayana Bot. 45:203-223. 